\title{
Review: Libya
}

Source: The Geographical Journal, Vol. 44, No. 3 (Sep., 1914), pp. 308-310

Published by: geographicalj

Stable URL: http://www.jstor.org/stable/1778693

Accessed: 27-06-2016 09:41 UTC

Your use of the JSTOR archive indicates your acceptance of the Terms \& Conditions of Use, available at

http://about.jstor.org/terms

JSTOR is a not-for-profit service that helps scholars, researchers, and students discover, use, and build upon a wide range of content in a trusted digital archive. We use information technology and tools to increase productivity and facilitate new forms of scholarship. For more information about JSTOR, please contact support@jstor.org.

The Royal Geographical Society (with the Institute of British Geographers), Wiley are collaborating with JSTOR to digitize, preserve and extend access to The Geographical Journal 
sympathy with her subject and inspires her reader with the same. She takes us through one town after another-Spoleto, Gubbio, and ten others, describing their buildings, some of which are curious blends of ancient Umbrian and comparatively modern architecture. Then follow descriptions of various fairs and religious festivals, and the industries, customs, and mode of life of the Umbrians who have retained so many old-world habits and faiths. Assisi, the mystic city, has, quite deservedly, a chapter to itself. The reproductions of Benvenuto's architectural photographs are most interesting, so are the delightful drawings by Venanzi.

'Handbook of Dalmatia.' By M. Seifert. (Vienna: A. Hartleben. Pp. xvi., 187. Maps, Plans, and Illustrations. 1913.) A guide to this Austrian province was much needed, for though Baedeker, Murray and Joanne include Dalmatia in their respective guides to Austria, yet in view of the importance of this new touring field, an independent guide to the district should be welcomed. The architectural attractions of Ragusa, Spalato, the wonderful ruins of Pola and the charming scenic features of this Adriatic Riviera are fully and conscientiously described. The English translation is not quite successful, and we find such sentences as " the visit requests an hour's time," but such literary shortcomings are of little moment in a guidebook. The practical details are very complete and ample, and the maps and plans are clear and accurate.

'The Russian Year-Book for 1914.' By H. P. Kennard, M.D. (London: Eyre and Spottiswoode. 1914. Pp. xx., 754. Diagrams. 10s.6d. net.) This Year-Book (which has now reached its fourth issue) has been intelligently compiled by Dr. Howard P. Kennard, and contains most of the information one usually expects in an annual work of reference of this kind. It has evidently been planned on the lines of a British Colonial Year-book, though unfortunately the Gazetteer section is omitted. It is unfortunate that the information is not always up to date; in fact, few of the statistical details have been brought down to a later date than 1912. This is, however, the only serious shortcoming. The sections dealing with the national resources of the country-mines, agriculture, \&.c-are remarkably full and informative. Tourists will find some valuable hints on the vexations and complex passport regulations, lut the section dealing with hotels is inadequate. The index is very full, but the biblingraphy is poor and of little value.

\section{AFRICA.}

IIBYYA.

'The Eastern Libyans.' An Essay by Oric Bates. London: Macmillan. 1914. Pp. xxii., 208. Illustrated.

'Strabos Erdkunde von Libyen.' By F. Strenger (Quellen und Forschungen . . . herausgegeben von W. Sieglin). Berlin : Weidmannsche Buchhandlung. 1913. Pp. 139.

Of these two important treatises on Libya, the second is purely geographical (ancient geography), while the first is in the main an archroological essay, prefaced by a section on the modern topography, and containing also a good deal of matter regarding ethnology, climatology, and so forth, as well as what is usually called ancient geography. Both are works of compilation, but their scope, character, and value differ. Dr. Strenger works from a literary standpoint, Mr. Bates from an archiological one. The former devotes himself to Quellen Kritik, the text of Strabo's seventeenth book, and is content to do the 
essential work preliminary to a definitive edition of that book. A critical edition of the whole text of Strabo is one of the things to be most devoutly desired at present. The manuscripts on which it rests leave it in a very corrupt and doubtful state; but nothing can be done usefully to emend it except comparative study of all other authorities for the ancient geography of the lands with which Strabo dealt. In this instance, that is to say, commentary must precede an edition of the text. That Dr. Strenger has made such a comparative study and supplied the necessary commentary to the Libyan chapters of Strabo will put all future editions in his debt.

Mr. Bates is more comprehensive but less conscious of the imperfections of his authorities. Confining himself to Eastern Libya (i.e. the region bounded on the east by the Nile and on the west by a line drawn south from the southernmost light of the Syrtis), he aims at summarizing all present knowledge of the country and its inhabitants with a view to elucidating Egyptian evidence for its ancient condition. So far as his descriptive chapters on geography and ethnology go, the labour and learning which have been devoted to their compilation are evident, but the authority to be attached to the statements in them is not so obvious. For one thing, it is far from clear how much of the country the author has seen for himself, and how much of the ethnological data which he uses he has had the opportunity to check. We gather that he has been in Cyrenaica, and on some parts of the coast of Marmarica. There is a suggestion that he has seen Siwah, but he does not say so explicitly; and about all other inland points, with which he deals, we feel equally uncertain. Not that he tries, for one moment, to create any false impression of autopsy, but, not realizing how great a difference in value there is between his own observation and his mere repetitions from others, he has left us in more than Herodotean perplexity. For example, take his brief notice of the Angila group of oases - is it based on anything more recent than Barth ? or, again, his description of the Chad road from Tripoli-is it based on recent information or on books older than Vischer's ? We doubt very much if Murzuk and Gatran can be rightly called "large towns" at the present day. This weakness re-appears in the arch wological parts of the book, where the very comprehensiveness of the treatment makes the reader uneasy. Is Mr. Bates, he asks, speaking at first hand of all his material alike? Is he to be accepted as an authority equally on things hieroglyphic, Greek, Arabic ? But on this point we must not insist in a Geographical Journal. We admire both the industry and the knowledge of Mr. Bates, but we hardly feel that he has succeeded in writing so authoritative a book on Eastern Libya, as we expected to read when this large and expensive volume came into our hands. It will be very useful as a guide to other authorities, and when those other authorities are referred to, it will no doubt often prove that Mr. Bates is right, but he will seldom save us the reference.

'The Bonds of Africa.' By Owen Letcher. (London : Long. 1913. Pp. 267. Map and Illustrations. 12s. 6d.) "Impressions of travel and sport"-thus the subtitle describes this work-" from Cape Town to Cairo, 1902-1912." The author has indeed ranged widely, through Rhodesia, Portuguese East Africa and Nyasaland, along the East Coast, through British East Africa, Uganda, and Egvpt. Humour, excitement, and able description are all present in his wellwritten narrative, which is pleasantly illustrated with photographs.

'Wild Game in Zambezia.' By R. C. F. Maugham. (London: Murray. 1914. Pp. xii., 376. Map and Illustrations. 12s.) This is a simple and 
exceedingly interesting narrative of sport, with the accompaniment of information about a territory of which parts are little known, that is natural to such a narrative. Some remarkable photographs of wild fauna illustrate it, and the map is well above the average. The author's views upon game preservation should command attention.

'The English People Overseas, vol. 6, South Africa, 1486-1913.' By A. Wyatt Tilby. (London: Constable. 1914. Pp. viii., 632. 7s. 6d.) "The present volume brings to a close the first part of this history of the English people overseas." It may be recalled that previous volumes carry the history of the American colonies down to 1763, of India down to 1828, of British North America down to 1867, of Britain in the Tropics down to 1910, and of Australia down to 1911. This is a very notable achievement, and the author's hope that he may continue the histories of India and of Canada, and deal with the English in the United States, will be echoed by many readers. The present volume maintains or improves the standard of its predecessors, and that is high praise. The writer deserves well of all students of the Empire, and his work should help to increase their number.

'Cairo of To-day.' By E. Reynolds-Ball. (London: Black. 1914. Pp. iv., 268. Maps and Illustrations. 2s. 6d.) The seventh edition of this convenient guide is brought, so far as can be judged, thoroughly up to date; rewriting has been involved in dealing with communications, etc., and the recent archæological work in Egypt receives full treatment, whereby the scope of the volume has been extended in a valuable way.

\section{AMERICA.}

\section{The Panama Canal.}

'La Nouvelle Voie Maritime : Le Canal de Panama.' By D. Bellet. Paris : Guilmoto. 1913. Pp. 330. Map. 5 francs.

'The Panama Canal.' By F. J. Haskin. London: Heinemann. 1914. Pp. xi., 385. Maps and Illustrations. 6 s.

These two works on the same subject differ markedly. The French volume is the more solid and methodical; here we find first a discussion on ship canals in general, next a survey of the Isthmus of Panama with a retrospect of the early plans for a canal through it, then the French scheme, and finally the American, treated in detail. The last section of the work deals with the future economic potentialities of the canal, and cites its financial aspects. Altogether this is a comprehensive work of reference on the great undertaking from every point of view. The English (or American) work is more discursive, and in its appreciation of the magnitude of the work and of its leaders more florid. Its chief interest (though the appeal is popular and the treatment not technical) is in the organization of the labour and in the engineering work, and the chapters on the latter subject carry the authority of Colonel Goethals.

' La Géographie de Terre-Neuve.' By R. Perret. (Paris: Guilmoto. 1913. Pp. vi., 373. Maps and Illustrations. 10 francs.) This book appears to provide a case (not of an uncommon type) of an authoritative work on the geography of a British territory by an author who is not British. We have here a detailed geographical survey, in which special attention is paid to natural features and natural science, chapters being devoted to the geology, to the physical geography, the climate, vegetation and fauna, and to the Grand Banks, before the economic, colonial, and political aspects are taken up. There is a very full biblio- 